\title{
Histomorphometric study on testes in rams fed with linseed oil rich in omega-3 and -6 polyunsaturated fatty acids
}

\section{ŽILVINAS VAŠKAS, ARTŪRAS ŠIUKŠČIUS, VIOLETA RAZMAITE்*, ALIUS POCKEVIČIUS**, NOMEDA JUODŽIUKYNIENE்**, JŪRATE் SABECKIENE்**, VIDA JUOZAITIENË***, SIGITA KERZIENE் ${ }^{* * * *}$, ALBINA ANIULIENE் $\dot{*}^{* *}$}

\author{
Department of Animal Reproduction, *Department of Animal Breeding and Genetics, Animal Science Institute, \\ Lithuanian University of Health Sciences, Žebenkos 12, 82317, Baisogala, Lithuania \\ **Department of Veterinary Pathobiology, Faculty of Veterinary Medicine, \\ Lithuania University of Health Sciences, Tilžès 18, 47181, Kaunas, Lithuania \\ ***Department of Animal Breeding and Nutrition, Faculty of Animal Husbandry Technology, \\ Lithuanian University of Health Sciences, Tilžès 18, 47181, Kaunas, Lithuania \\ ****Department of Physics, Mathematics and Biophysics, \\ Lithuanian University of Health Sciences, Tilžès 18, 47181, Kaunas, Lithuania
}

\section{Vaškas Ž., Šiukščius A., Razmaitè V., Pockevičius A., Juodžiukynienė N., Sabeckienè J., Juozaitienè V., Kerzienè S., Aniulienè A. \\ Histomorphometric study on testes in rams fed with linseed oil rich in omega-3 and -6 polyunsaturated fatty acids}

Summary

Many researchers have pointed out that the intake of omega-3 and -6 fatty acids is beneficial to animal health and reproductive capacity, but the effect of fatty acids on the histomorphology of ram testes is still unknown. The aim of this study was to investigate the effect of linseed oil containing polyunsaturated fatty acids on the morphology and histomorphometric characteristics of ram testis and epididymis. Testes of 12 Lithuanian local coarse wool rams were investigated histomorphologically and histomorphometrically in the present work. The rams were divided into two groups, an experimental group and a control group following, the principle of analogues - the same origin, age, weight, and condition score. The experimental group $(n=6)$ received $2 \%$ linseed oil sediments while the control group $(n=6)$ received $1.2 \%$ sunflower oil for 9 months. The diameter of testicular tubules and the height of the germinal epithelium, the spermatogenic index and the number of Leydig cells were higher in the experimental group than those in the control group. In addition, the number of degenerated tubules was not significantly lower in the group that received $2 \%$ linseed oil sediments. Still, the height of the epididymal epithelium was lower than that in the control group.

Keywords: ram, linseed oil, omega-3 and -6 polyunsaturated fatty acids, testis, histomorphometry

Polyunsaturated fatty acids (PUFAs) n-3 and n-6 are necessary for the body's metabolism, growing, brain development, vision, health, meat quality and reproduction $(2,9,11,16,30)$. Animals cannot synthesize n-3 or n- 6 fatty acids, and therefore these fatty acids have to be provided in the diet. Still, there is little information about the beneficial effect of $n-3 / n-6$ ratios on male (men, boars) and female reproduction performance $(4,18,22,23,25,28)$. According to Yan et al. (28), following the intake of $n-3 / n-6$, spermatogonial and spermatocyte development was better than that in the control group, and the distribution of chromatin around the nuclear membrane was more uniform.
However, no information about the effect of $n-3 / n-6$ PUFA ratios on ram reproduction is available.

The aim of this study was to investigate the effect of linseed oil containing polyunsaturated fatty acids on the histomorphometric characteristics of the ram testis.

\section{Material and methods}

In the present study, testes from 12 Lithuanian local coarse wool rams were taken and investigated histomorphologically and histomorphometrically. The investigations were performed in compliance with the Lithuanian animal welfare regulations (No. B1 - 866, 2012; No. XI - 2271, 2012) and were approved by the Lithuanian Committee of 
Veterinary Medicine and Zootechnics Sciences (Protocol No. 07/2010). In accordance with the principle of analogues, i.e. the same origin, age, weight and meatiness, the rams were divided into two groups containing 6 animals each. The initial weight of the rams was $21.11 \pm 1.048 \mathrm{~kg}$ (age -4 months) and $54.50 \pm 1.504 \mathrm{~kg}$ (age -13 months). The animals were kept in similar conditions. In summer, the rams of both groups were kept in field enclosures of 40 ares, seven animals in each. Shelters were built to protect them from exposure to rain, bad weather and the sun. Feeders for additional feeding were sheltered from atmospheric precipitation. The rams were watered from different troughs. In winter, both groups of rams were kept in cotes, 6 animals in each. They were fed from special feeders. Water was supplied in separate troughs.

During the experiment, the rams of both groups were given ad libitum access to pasture grass in summer and hay from cultivated grasslands in winter. The rams were additionally fed with compound feed, whose composition and nutritional values are given in Table 1 . The feeders were filled twice a day on a daily basis. The compound feed was prepared at the Testing Department of LUHS AHI from farm feed materials.

For the control group (Group 1) of rams, sunflower oil was added to the compound feed as an energy source. For

Tab. 1. Composition and analysis of compound feed

\begin{tabular}{|l|c|c|}
\hline \multirow{2}{*}{ Indices } & \multicolumn{2}{c|}{ Experiment } \\
& Control & Experimental \\
\hline Barley, \% & 36.8 & 36.6 \\
\hline Oats, \% & 36 & 36 \\
\hline Sunflower meal, \% & 21.7 & 21.1 \\
\hline Sunflower oil, \% & 1.2 & - \\
\hline Sediments of linseed oil, \% & - & 2 \\
\hline Limestone, \% & 0.3 & 0.3 \\
\hline Premix for sheep 4, \%* & 4 & 4 \\
\hline Premix DPF 12454 Normal 1/9-15/7, \%** & - & - \\
\hline Analytical data/kg feed: & & \\
\hline dry matter, kg & 0.872 & 0.873 \\
\hline metabolizable energy, MJ & 10.1 & 10.1 \\
\hline crude protein, g & 160.0 & 160.0 \\
\hline fibre, g & 93.5 & 92.4 \\
\hline calcium, g & 11.7 & 11.7 \\
\hline phosphorus, g & 7.0 & 7.0 \\
\hline
\end{tabular}

Explanations: *Content of premix for sheep 4: calcium - $160 \mathrm{~g} / \mathrm{kg}$; phosphorus - $60 \mathrm{~g} / \mathrm{kg}$; sodium - $50 \mathrm{~g} / \mathrm{kg}$; magnesium - $50 \mathrm{~g} / \mathrm{kg}$; manganese $-2000 \mathrm{mg} / \mathrm{kg}$; zinc $-2000 \mathrm{mg} / \mathrm{kg}$; iodine $-25 \mathrm{mg} / \mathrm{kg}$; selenium - $10 \mathrm{mg} / \mathrm{kg}$; vitamin A - $150000 \mathrm{IU}$; vitamin $\mathrm{D}_{3}-15000$ IU; vitamin E - $5000 \mathrm{mg} / \mathrm{kg}$; biotin $-500 \mathrm{mg} / \mathrm{kg}$. ** Content of premix DPF 12454 Normal 1/9-15/7: calcium - $410 \mathrm{~g} / \mathrm{kg}$; phosphorus $-80 \mathrm{~g} / \mathrm{kg}$; iron fumerate $-91596 \mathrm{mg} / \mathrm{kg}$; manganic oxide $-10060 \mathrm{mg} / \mathrm{kg}$; zinc oxide $-16747 \mathrm{mg} / \mathrm{kg}$; sodium selenite - $176 \mathrm{mg} / \mathrm{kg}$; vitamin A - $800000 \mathrm{IU}$; vitamin $\mathrm{D}_{3}-280000 \mathrm{IU}$; vitamin $\mathrm{E}-21000 \mathrm{IU}$; vitamin $\mathrm{B}_{1}-12000 \mathrm{mg} / \mathrm{kg}$; vitamin $\mathrm{B}_{2}-$ $4801 \mathrm{mg} / \mathrm{kg}$; vitamin $\mathrm{B}_{6}-3201 \mathrm{mg} / \mathrm{kg}$; vitamin $\mathrm{B}_{12}-16 \mathrm{mg} / \mathrm{kg}$; pantothenic acid - $3207 \mathrm{mg} / \mathrm{kg}$; niacin - $8002 \mathrm{mg} / \mathrm{kg}$; biotin $80 \mathrm{mg} / \mathrm{kg}$; folic acid $-400 \mathrm{mg} / \mathrm{kg}$ the experimental group (Group 2) of rams, the compound feed was supplemented with $2 \%$ linseed oil in liquid sediments instead of sunflower oil (Tab. 1,2).

The chemical composition of the feed was examined at the Chemistry Laboratory of the Animal Science Institute of LUHS in accordance with the standard methods, the AOAC (1990). The accounting of combined feed was carried out by weighing the feed for each individual enclosure or cage. To determine the growth rate of rams, they were weighed at the beginning and at the end of the experiment.

After slaughter, pairs of testes were obtained from mature rams. Testes of each ram were weighed and measured; two

Tab. 2. Chemical composition of sunflower oil and sediments of linseed oil

\begin{tabular}{|l|c|c|}
\hline \multicolumn{1}{|c|}{ Components } & $\begin{array}{c}\text { Sediments of } \\
\text { linseed oil }\end{array}$ & Sunflower oil \\
\hline Metabolizable energy, MJ/kg & 24.00 & 33.00 \\
\hline Fat, $\mathbf{g} / \mathrm{kg}$ & 702.0 & 1000.00 \\
\hline Fatty & & \\
\hline
\end{tabular}

\begin{tabular}{|c|c|c|}
\hline \multicolumn{3}{|l|}{ Fatty acids, $g / k g$ in fat/in feed } \\
\hline Lauric (C12:0) & - & - \\
\hline Myristic (C14:0) & $0.4 / 0.28$ & 0.6 \\
\hline Myristoleic (C14:1) & - & - \\
\hline Pentadekanoic (C15:0) & $0.2 / 0.14$ & - \\
\hline Palmitic (C16:0) & $52.8 / 37.07$ & 59.5 \\
\hline Palmitoleic (C16:1n-9) & $0.2 / 0.14$ & - \\
\hline Hexadecenoic (C16:1n-7) & $0.6 / 0.42$ & 0.8 \\
\hline Margaric (C17:0) & $0.6 / 0.42$ & 0.3 \\
\hline Heptadecenoic (C17:1n-9) & $0.3 / 0.21$ & 0.2 \\
\hline Stearic (C18:0) & $36.7 / 25.77$ & 33.7 \\
\hline Oleic (C18:1n-9) & $204.7 / 143.70$ & 264.4 \\
\hline Elaidic (C18:1n-9 T) & $0.2 / 0.14$ & 0.5 \\
\hline Linolelaidic (C18:2n-6 T) & $0.4 / 0.28$ & 2.2 \\
\hline Linoleic (C18:2n-6) & $187.4 / 131.56$ & 614.0 \\
\hline Vaccenic (C18:1n-7) & $6.2 / 4.35$ & 6.9 \\
\hline$\alpha$-linolenic (C18:3n-3) & $502.7 / 352.90$ & 3.3 \\
\hline$\gamma$-linolenic (C18:3n-6) & $1.5 / 1.05$ & - \\
\hline Arachidic (C20:0) & $1.2 / 0.84$ & 2.3 \\
\hline Eicosenoic (C20:1n-9) & $0.4 / 0.28$ & 1.6 \\
\hline Eicosadienoic (C20:2n-6) & $0.3 / 0.21$ & 0.2 \\
\hline Eicosatrienoic (C20:3n-3) & $0.5 / 0.35$ & - \\
\hline Arachidonic (C20:4n-6) & $0.2 / 0.14$ & 0.3 \\
\hline Heneicosanoic (C21:0) & $0.3 / 0.21$ & - \\
\hline Begenic (C22:0) & $0.7 / 0.49$ & 6.4 \\
\hline Erucic (C22:1n-9) & $0.3 / 0.21$ & - \\
\hline Docosatetraenoic (C22:4n-6) & $0.2 / 0.14$ & 0.4 \\
\hline Docosapentaenoic (C22:5n-3) & $0.4 / 0.28$ & - \\
\hline Lignoceric (C24:0) & $0.6 / 0.42$ & 2.0 \\
\hline Nervonic (C24:1n-9) & - & 0.4 \\
\hline Dokozotetraenoic (C22:4n-6) & $0.2 / 0.14$ & 0.4 \\
\hline Dokozopentaenoic (C22:5n-3) & $0.4 / 0.28$ & - \\
\hline Lignocerinic (C24:0) & $0.6 / 0.42$ & 2.0 \\
\hline
\end{tabular}


specimens were taken from each testicle, and one sample was taken from the head of the epididymis for histopathological examination. One sample was taken from the caudoventral part and the other from the craniodorsal part of both testicles. The specimens of testes were placed in Bouin's solution for 24 hours and then stored in 70\% ethyl alcohol. Paraffin blocks were made using Shandon Pathcentre and TES 99 Medite Medizintechnik equipment. Serial $4-\mu \mathrm{m}$ sections for routine $\mathrm{H} \& \mathrm{E}$ staining were prepared from each sample with a Sakura Accu-Cut SRM microtome. The diameter of 200 tubules that were round or nearly round was measured in the right and left testes in each animal. The diameter of the seminiferous tubule was measured across the minor and major axes, and the mean diameter was obtained. The height of the germinal epithelium was measured at $400 \times$ magnification. The germinal epithelium height (distance from the basement membrane to the luminal edge) was measured in the same section in which the tubule diameter was obtained. Two diametrically opposite readings were taken using a digital ruler on each cross section, using their mean value. Testis tubules were assessed using the spermatogenic index (SI) developed by Grocock and Clarke (8). The scores assigned ranged from 1 to 5 . Score 5 was given to tubules displaying complete spermatogenesis; score 1 was assigned to tubules that contained primary Sertoli cells, spermatogonia, and primary spermatocytes. The number of Leydig cells was measured at 40 fields $400 \times$ magnification in an area of $160 \times 220 \mu \mathrm{m}$. The ductal epithelium height (the distance from the basement membrane to the luminal edge) of 50 tubules was measured in the epididymis.

Statistical analysis was performed using the SPSS program 20.0 for Windows. The experimental data were normally distributed (Kolmogorov-Smirnov test). The results are presented as the mean and the standard error of the mean (mean \pm SEM). The significance of differences between the mean values for the ram groups was determined using Student's test for independent samples. We evaluated the influence of fixed factors and their interaction on the histomorphometric parameters of the ram groups examined.

The variables investigated were analyzed using the following linear model:

$$
\mathrm{Y}_{\mathrm{ijk}}=\mu+\mathrm{G}_{\mathrm{i}}+\mathrm{T}_{\mathrm{j}}+\mathrm{GT}_{\mathrm{ij}}+\mathrm{e}_{\mathrm{ijk}} \text {, }
$$

where $Y_{i j k}$ is the dependent variable, $\mu$ is the general mean, $\mathrm{G}_{\mathrm{i}}$ is the group of rams (group 1 is experimental, group 2 is control), $T_{j}$ is testes (class 1 is the left testis and class 2 is the right testis), $\mathrm{GT}_{\mathrm{ij}}$ is the effect of the group and testes interaction, and $\mathrm{e}_{\mathrm{ijk}}$ is a residual error.

\section{Results and discussion}

The weight and size of testes in both groups did not show significant variation. The diameter of the testis in the control group was $29.85 \mathrm{~cm}$, and that in the experimental group was $30 \mathrm{~cm}$. When rams' diets contained $\mathrm{n}-3 / \mathrm{n}-6$, the development of their testes was more intensive $(16,28)$. The testicular parenchyma is a functional part of the testis and consists of two compartments: a tubular compartment and an interstitial one (21). Tubular measurement is one of the approaches used as a spermatogenic indicator in experiments related to the testicular function $(3,6,20)$. Differences between the parameters in the experimental and control groups depending on omega- 3 and -6 polyunsaturated fatty acids are presented in Table 3. The diameter of testicular tubules in the experimental group $(295.9 \pm 4.89 \mu \mathrm{m})$ was $41.3 \mu \mathrm{m}$ larger $(\mathrm{p}<0.001)$ as compared with that of the control group but did not exceed the upper physiological limit. The tubular diameter ranged from 55.24 to $592.88 \mu \mathrm{m}$ in the experimental group and from 72.07 to $433.54 \mu \mathrm{m}(\mathrm{p}<0.001)$ in the control group. The average diameter for the majority of amniotes ranges from 180 to $300 \mu \mathrm{m}$ (19), in goats it measures up to 237.0 (12) and can reach $550 \mu \mathrm{m}$ in some species of marsupials (27). The germinal epithelium height of the testes was $15.2 \mu \mathrm{m}$ larger $(\mathrm{p}<0.001)$ in the experimental group. The analysis of the results demonstrated that the height of the germinal epithelium varied from 38.55 to $161.83 \mu \mathrm{m}$ in the experimental group and from 15.58 to $130.76 \mu \mathrm{m}$ in the control group and was within the range observed for domestic animals $(60-100 \mu \mathrm{m})$ (10). The height of the seminiferous epithelium is essential for the evaluation of sperm production (26). The epididymal epithelium height was $13.7 \mu \mathrm{m}$ lower in the experimental group than that in the control group $(\mathrm{p}<0.01)$ and ranged between 9.67-90.71 $\mu \mathrm{m}$ and 14.31-137.25 $\mu \mathrm{m}(\mathrm{p}<0.001)$, respectively. In addition, the spermatogenic index was 0.37 scores higher $(\mathrm{p}<0.01)$, and the number of Leydig cells was 37.9 cells greater $(p<0.001)$ in the experimental group as compared with that in the control group. The range of the spermatogenesis index was scored 1.8 (from 3.10 to 4.90 ) in the experimental group and 1.7 (from 2.90 to 4.60$)$ in the control group $(p<0.001)$. The spermatogenic index is a comparative measure of the extent of spermatogenesis in the germinal epithelium (29). The testicular tissue and the spermatogenesis process are highly sensitive to oxidative stress, as well as physical and chemical agents, $(7,15,17)$, which lead to the degeneration of spermatogenic cells. In our experiment, we determined a mild degeneration of some testicular tubules in both groups of animals. The 
range of degenerated tubules accounted for $9 \%$ (from 3.5 to 12.5 ) in the experimental group and for $22.5 \%$ (from 6.5 to 29.0) in the control group (p<0.001). These changes obviously had some impact on the histomorphometric results, but the smaller number of degenerated tubules in the experimental group means that $n-3 / n-6$ PUFAs have a positive influence on testicular health and function.

The left and right testicles did not differ between the groups in most characteristics (Fig. 1-2).

Differences in the tubular diameter and the number of Leydig cells between the left and right testis in the experimental and control groups were not statistically significant (Fig. 1).

The height of the epididymal epithelium (Fig. 2) of

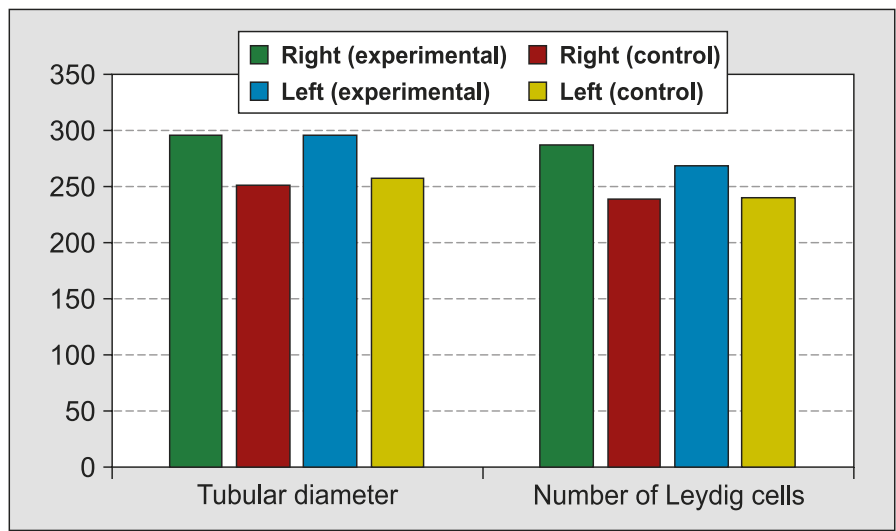

Fig. 1. The diameter of the seminiferous tubules and the number of Leydig cells in both testes in control and experimental groups the right testis in the experimental group was $11.52 \mu \mathrm{m}$ larger as compared with that of the left testis $(p>0.05)$. A greater number of degenerated tubules (15.2-15.3) was found in the right testis in the experimental and control groups $(\mathrm{p}>0.05)$. A comparison of indicators for the left and right testicles between the experimental and control groups is presented in Fig. 3. The analysis showed differences between the experimental and control groups in most characteristics of the left testis - from $10.5 \%$ (the number of Leydig cells, $\mathrm{p}<0.05$ ) to $64.9 \%$ (the height of the epididymal epithelium, $\mathrm{p}<0.01)$ - and of the right testis - from $5.7 \%$ (the number of degenerated tubules, $p>0.05$ ) to $25.0 \%$ (the height of the epididymal epithelium, $\mathrm{p}<0.01)$.

The results of the ANOVA model are presented in Tab. 4.

We estimated that the strongest influence on the parameters investigated (tubular diameter and the height of the germinal epithelium of the testes, the number of Leydig cells, the spermatogenesis index, the height of the epididymal epithelium and the number of degenerated tubules) $(p=0.002-0.0001)$ depended on the group of rams (Tab. 3). A statistically significant influence of the testes on the number of

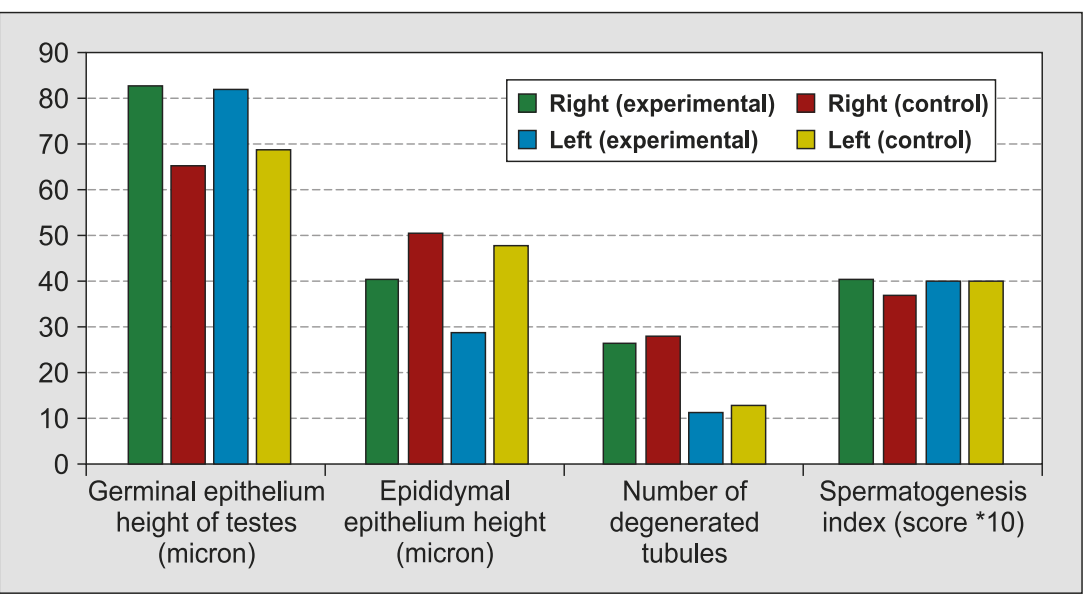

Fig. 2. Parameters of both testes in control and experimental groups

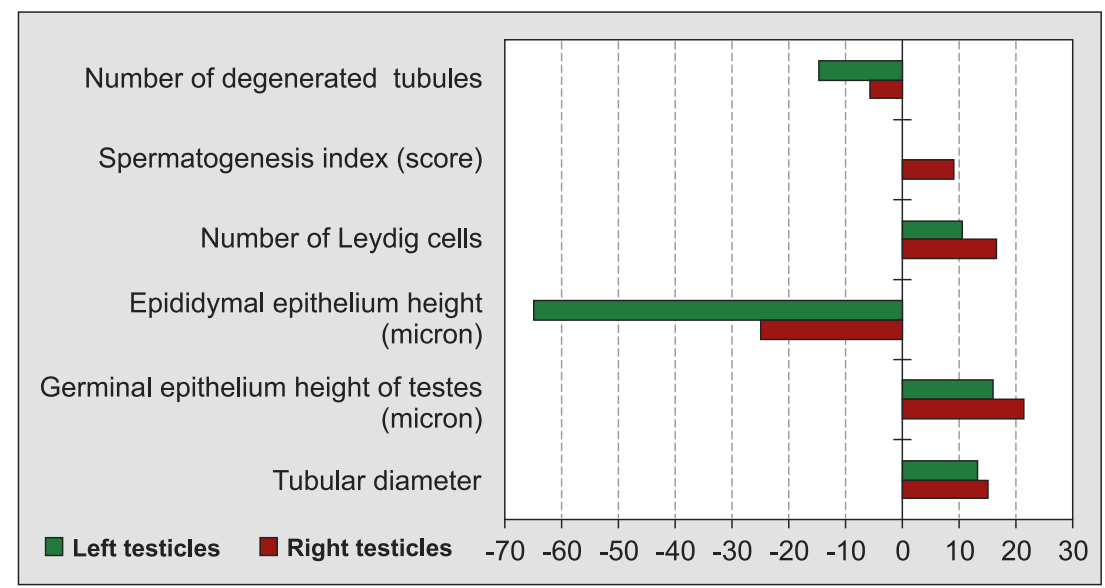

Fig. 3. Differences $(\%)$ in the parameters of both testes in experimental and control groups
Leydig cells $(\mathrm{p}=0.011)$ and the spermatogenesis index $(p=0.001)$ was estimated. Interaction between the group and the testes significantly influenced the spermatogenesis index $(p=0.001)$ and the number of Leydig cells $(p=0.011)$.

Experiments carried out by other scientists demonstrated that the intake of
Tab. 4. Influence of fixed factors and their interaction on histomorphometric characteristics of ram testis

\begin{tabular}{|c|c|c|c|c|c|}
\hline Parameters & $\mathbf{G}_{\mathbf{i}}$ & $T_{i}$ & $\mathrm{GT}_{\mathrm{ij}}$ & Model & $\mathbf{R}^{2}$ \\
\hline Tubular diameter $(\mu \mathrm{m})$ & 0.0001 & 0.838 & 0.546 & 0.0001 & 0.997 \\
\hline Germinal epithelium height of the testes (micron) & 0.0001 & 0.468 & 0.537 & 0.0001 & 0.994 \\
\hline Epididymal epithelium height ( $\mu \mathrm{m})$ & 0.002 & 0.082 & 0.278 & 0.0001 & 0.963 \\
\hline Number of Leydig cells & 0.001 & 0.017 & 0.011 & 0.0001 & 0.996 \\
\hline Spermatogenesis index (score) & 0.001 & 0.005 & 0.001 & 0.0001 & 0.999 \\
\hline Number of degenerated tubules & 0.580 & 0.002 & 0.672 & 0.0001 & 0.813 \\
\hline
\end{tabular}


n-3 fatty acids was beneficial to male reproductive capacity, resulting in histological and ultra-structural changes in the testis and sperm, better spermatogonial development, a larger number of germ cell layers (5), an increased total number of sperm per ejaculation, greater sperm quality, density and motility, as well as an increased membrane integrity of sperm in humans and animals $(4,18,22,23,25,28)$, which may be related to changes in hormone metabolism (16). Leydig cells are the most important source of androgen. More than $90 \%$ of all androgens in the organism are produced by the testes. Leydig cells constitute approximately $1 \%$ of the entire testicular volume in adult rams. In this study, we found that the number of Leydig cells was higher in the experimental group than that in the control group. Veldhuis et al. (24), Yan et al. (28), and Feng et al. (5) established that an increase in the ratio of $n-3 / n-6$ PUFAs significantly affected serum reproductive hormone levels, increasing the concentrations of $\mathrm{GnRH}$, $\mathrm{FSH}, \mathrm{LH}$, and T. FSH plays a role in spermatogenesis (24), LH stimulates the interstitial cells located in the testes to produce testosterone. Putting rams on a high energy diet increased GnRH pulse frequency, testicular mass, and sperm production (13), whereas a decrease in the LH pulse frequency of mature male sheep was observed after the reduction of feed intake (14).

The present study is the first to describe the effect of omega- 3 and -6 on the morphology of the testis and the spermatogenic process in rams. The intake of an appropriate $n-3 / n-6$ PUFA ratio in the diet of rams increased seminiferous tubule and Leydig cell parameters and thus improved reproductive performance, which may be related to changes in hormone metabolism. The diameter of testicular tubules, the height of the germinal epithelium, the spermatogenic index and the number of Leydig cells were higher in the experimental group than they were in the control group. Moreover, the number of degenerated tubules was not significantly lower in the group, which received sediments of $2 \%$ linseed oil, whereas the height of the epididymal epithelium was lower than that in the control group. The results might be of value for future studies.

\section{References}

1. Blesbois E., Douard V., Germain M., Boniface P., Pellet F.: Effects of n-3 polyunsaturated dietary supplementation on the reproductive capacity of male turkeys. Theriogenol. 2004, 61, 537-549.

2. Borys A., Borys B., Janicki B., Jarzynowska A.: Effects of different particle size of rapeseed and linseed in fattening lamb diets. I. Growth and slaughter performance, [in:] Priolo A., Bion di L., Ben Salem H., Moran d-Fehr P. (eds): Advanced Nutrition and Feeding Strategies to Improve Sheep and Goat. CIHEAM Zaragoza 2007, p. 77-82.

3. Costa K. L., da Matta S. L., de Lucca M. G. M., de Paula T. A. R., de Freitas K. M., Carvalho F. A. R., Silveira J. A., Dolder H., Chramindrani S. M. L.: Histomorphometric evaluation of the neotropical brown brocket deer Mazama gouazoubira testis, with an emphasis on cell population indexes of spermatogenic yield. Anim. Reprod. Sci. 2011, 127, 202-212.

4. Estienne M. J., Harper A. F., Crawford R. J.: Dietary supplementation with a source of omega-3 fatty acids increases sperm number and the duration of ejaculation in boars. Theriogenol. 2008, 70, 70-76.
5. Feng Y., Ding Y., Liu J., Tian Y., Yang Y., Guan S, Zhang C.: Effects of dietary omega-3/omega- 6 fatty acid ratios on reproduction in the young breeder rooster. BMC Vet. Res. 2015, 11, 73.

6. Franca L. R., Cardoso F. M.: Duration of spermatogenesis and sperm transit time through the epididymis in the piau boar. Tiss. Cell. 1998, 30, 573-582.

7. Gotowiecka M., Niżański W., Partyka A., Strzeżek R., Koziorowska-Gilun M.: Assessment of the influence of oxidative stress on animal semen. Med. Weter. 2015, 71, 743-747.

8. Grocock C. A., Clarke J. R.: Photoperiodic control of testis activity in the vole, Microtus Agrestis. J. Reprod. Fert. 1974, 39, 337-347.

9. Gurr M. I., Harwood J. L., Frayn K. N.: Lipid Biochemistry: An Introduction, ( $5^{\text {th }}$ edit.), Blackwell Science Ltd, Oxford, UK 2002.

10. Hess R. A., Franca L. R.: Spermatogenesis and cycle of the seminiferous epithelium, [in:] Cheng C. Y. (ed.): Molecular Mechanisms in Spermatogenesis. Landes Bioscience 2008, p. 1.

11. Kolanowski $W$ : Role of omega-3 polyunsaturated fatty acids in the course of inflammation. Med. Weter. 2015, 71, 608-614.

12. Leal M. C., Becker-Silva S. C., Chiarini-Garcia H., Franca L. R.: Sertoli cell efficiency and daily sperm production in goats (Capra hircus). Anim. Reprod. 2004, 1, 122-128.

13. Martin G. B., Tjondronegoro S., Blackberry M. A.: Effects of nutrition on testicular size and the concentrations of gonadotrophins, testosterone and inhibin in plasma of mature male sheep. J. Reprod. Fertil. 1994, 101, 121-128.

14. Martin G. B., Walkden-Brown S. W.: Nutritional influences on reproduction in mature male sheep and goats. J. Reprod. Fertil. Suppl. 1995, 49, 437-449.

15. Orzotek A., Mietelska K., Wysocki P.: Function of the antioxidant system in boar semen. Med. Weter. 2016, 72, 291-297.

16. Rahman M. M., Gasparini C., Turchini G. M., Evans J. P.: Experimental reduction in dietary omega-3 polyunsaturated fatty acids depresses sperm competitiveness. Biol. Lett. 2014 Sep;10. pii: 20140623. doi: 10.1098/ rsbl.2014.0623.

17. Razi M., Najafi G., Feyzi S., Karimi A., Shahmohamadloo S., Nejati V.: Histological and histochemical effects of Glyphosate on testicular tissue and function. Iran J. Reprod. Med. 2012, 10, 181-192.

18. Rooke J. A., Shao C. C., Speake B. K.: Effects of feeding tuna oil on the lipid composition of pig spermatozoa and in vitro characteristics of semen. Reprod. 2001, 121, 315-322.

19. Roosen-Runge E. C.: The process of spermatogenesis in animals. Academic Press, Cambridge, UK 1977.

20. Russell L. D., Chandrashekar V., Bartke A., Sinha-Hikim A. P.: The hamsters Sertoli cell in early testicular regression and early recrudescence: a steorological and endocrine study. J. Androl. 1994, 17, 93-106.

21. Russell L. D., Ettlin R. A., Sinha Hilim A. P., Clegg E. D.: Mammalian spermatogenesis, [in:] Russell L. D., Ettlin R. A., Sinha Hilim A. P., Clegg E. D. (eds): Histological and Histopathological Evaluation of the Testis. Cache River Press, USA 1990, p. 32.

22. Safarinejad M. R., Safarinejad S.: The roles of omega-3 and omega-6 fatty acids in idiopathic male infertility. Asian J. Androl. 2012, 14, 514-515.

23. Strzezek J., Fraser L., Kuklińska M., Dziekońska A., Lecewicz M.: Effects of dietary supplementation with polyunsaturated fatty acids and antioxidants on biochemical characteristics of boar semen. Reprod. Biol. 2004, 4, 271-287.

24. Veldhuis J. D., Keenan D. M., Liu P. Y., Iranmanesh A., Takahashi P. Y., Nehra $A$. $X$ : The aging male hypothalamic-pituitary-gonadal axis: pulsatility and feedback. Mol. Cell Endocrinol. 2009, 299, 14-22.

25. Wathes D. C., Abayasekara D. R., Aitken R. J.: Polyunsaturated fatty acids in male and female reproduction. Biol. Reprod. 2007, 77, 190-201.

26. Wing T. Y., Christensen A. K.: Morphometric studies on rat seminiferous tubules. AM J. Anat. 1982, 165, 13-15.

27. Woolley P.: The seminiferous tubules in dasyurid marsupials. J. Reprod. Fertile. $1975,45,255-261$

28. Yan L., Bai X. L., Fang Z. F., Che L. Q., Xu S. Y., Wu D.: Effect of different dietary omega-3/omega-6 fatty acid ratios on reproduction in male rats. Lipids Health Dis. 2013, 12, 33 .

29. Young K. A., Zirkin B. R., Nelson R. J.: Testicular regression in response to food restriction and short photoperiod in white-footed mice (Peromyscus leucopus) is mediated by apoptosis. Biol. Reprod. 2000, 62, 347-354.

30. Zsédely E., Király A., Szabó Cs., Németh K., Dóka O., Schmidt J.: Effect of Dietary Linseed Oil Soap on Lamb Meat. International J. Med. Biol. Sci. 2012, $6,142-145$.

Corresponding author: Žilvinas Vaškas, DVM, PhD student, Department of Animal Reproduction, Animal Science Institute, Lithuanian University of Health Sciences, Žebenkos 12, 82317, Baisogala, Lithuania; e-mail: zilvinas. vaskas@Ismuni.It 